\title{
VSC- based HVDC System Capability to Ride Through Faults
}

\author{
O. Abarrategui, D.M. Larruskain, I. Zamora, V. Valverde, G. Buigues, A. Iturregi \\ Department of Electrical Engineering \\ EUITMOP, UPV/EHU \\ Rafael Moreno Pitxitxi 2, 48013 Bilbao (Spain) \\ Phone/Fax number:+0034 94601 4971, e-mail: oihane.abarrategui@ehu.es,
}

\begin{abstract}
VSC-HVDC is becoming an increasingly attractive technology for power network development. In order to establish itself a viable alternative it still has to address some issues, e.g., its response under fault situations on both $\mathrm{AC}$ and DC side. This paper makes a state-of-the-art review on how different converter topologies affect the Fault Ride Through (FRT) ability of the system. By comparing the different converter topologies, it is possible to underline the features that will be able to guarantee a successful FRT, which can be very helpful in order to choose the most suitable converter topology for different applications.
\end{abstract}

\section{Key words}

VSC-HVDC, Fault Ride-Through, Modular Multilevel Converter (MMC), MTDC.

\section{Introduction}

Nowadays, VSC based HVDC transmission systems have become competitive in terms of power handling capability, DC operating voltage, semiconductor losses, as well as reliability and technology maturity. VSC converters have evolved from basic 2-level converters to more complex but better performing devices: Modular Multilevel Converters (MMC). In fact, under disturbances in both $\mathrm{AC}$ and DC side networks, the dynamic behavior in these VSC-based systems is highly influenced by the converter topologies used.

VSC-HVDC technology provides independent control of both active and reactive power, generates high quality voltage waveforms, provides voltage support by generating lagging and leading reactive power, needs less filtering infrastructure and has black-start capability, as well as the ability to operate in weak AC networks, such as offshore wind farms. Furthermore, power reversal is achieved without the need of a DC voltage polarity change [1].

Notwithstanding that, VSC-HVDC systems are quite vulnerable to DC side faults and the lack of circuit breakers (CB) capable of operating at high voltage DC levels is also a major drawback. Therefore, VSC system applications are often restricted to point-to-point connections. In this regard, many classic point-to-point and multiterminal VSC-HVDC (MTDC) systems do not have the ability to ride through severe DC faults. On the contrary, most of these systems show a good behavior towards AC side faults.

The current trend in VSC-HVDC transmission systems for fault ride-through (FRT) lies in the control system of the converters and, at the same time, in the effective impedance between the point-of-common-coupling (PCC) and the converter terminals. Nevertheless, it has been established that recovery from disturbances is highly system dependent [2].

Thus, this paper analyzes and compares different converter topologies and their behavior under different kinds of faults. Firstly, a wide analysis of the more problematic DC side faults is performed, especially focusing on different Modular Multilevel Converter (MMC) topologies and then, the case of AC side faults is considered. The main features of the different converters are compared, highlighting those more favorable to a fault tolerant behavior.

\section{DC Fault Ride Through}

The converter technologies currently available allow that, during the DC side fault, AC side contributes to the fault current through the freewheeling diodes. Also, discharge currents from the capacitors add to the fault current transient dynamics.

Therefore, fault interruption needs CBs that tolerate high currents during the first cycles after the fault occurs, along with high current breaking capacity and fast interruption time. These characteristics are difficult to obtain, besides many proposed $\mathrm{CB}$ designs may introduce significant steady-state losses due to the semiconductors in the main current path.

The converter station topology is of the utmost importance when it comes to FRT capabilities. Thus, a study of the different topologies and their FRT capabilities is developed in this section. 


\section{A.2-Level Converter}

2-level converters (see Fig.1) present certain disadvantages, such as high conversion losses and the need of a transformer with high insulation requirements. When subjected to a pole-to-pole DC fault, active power drops to zero but reactive power flows from the AC side to the converter, increasing the current due to $\mathrm{AC}$ grid contribution through the freewheeling diodes, causing a severe voltage dip. After fault clearance AC side converter switches experience high inrush currents while the DC side rebuilds itself [3].

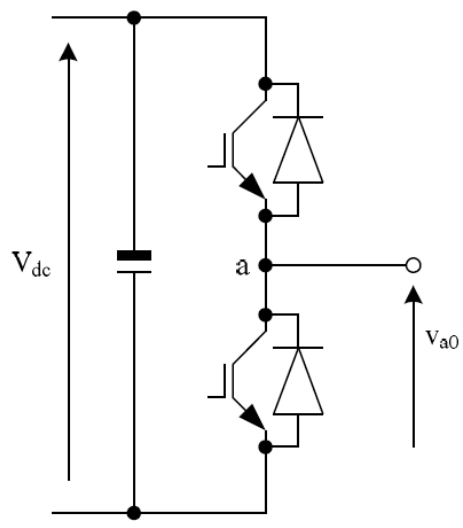

Fig. 1. 2-level converter [3].

\section{B. Neutral Point Clamped (NPC) Converter}

When this type of converters (Fig. 2) are exposed to a solid pole-to-pole fault, the current stresses on converter switches can be reduced using significantly large effective impedance between converter and the PCC. However, the reactive power capability of the converter suffers.

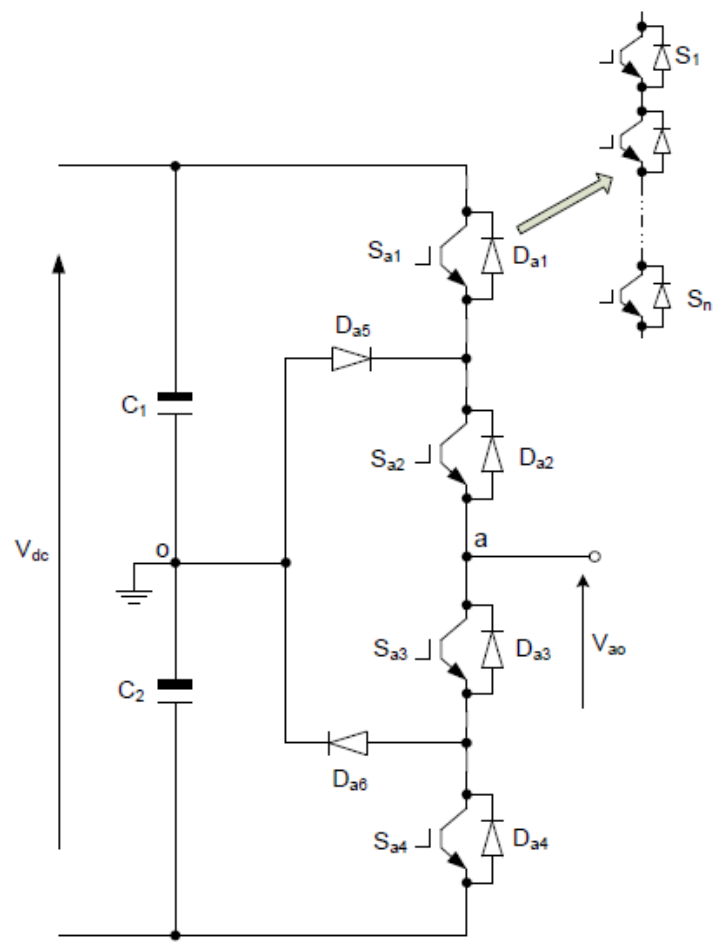

Fig. 2. NPC converter [11].
Compared to the 2-level converter, the NPC converter slightly improves FRT capability, but it may still be considered as poor. Besides, converter switches are exposed to twice their rated voltage during pole-to-ground fault [4].

\section{Modular Multilevel Converters (MMC)}

There are different kinds of MMC topologies, each of them showing a different behaviour to FRT.

\section{1) Half Bridge Modular Multilevel Converters (HBMMC).}

This device (Fig. 3) is vulnerable to DC faults because the inability of half-bridge cells to produce a negative voltage results in the conduction through the freewheeling diodes. Thus, the AC side will contribute to the fault current and the inrush current is a problem for fault ride-through capability.

Notwithstanding that, the arm inductances contribute to the DC side FRT capability and the distributed capacitors do not discharge during DC faults, removing one of the main contributors to fault current during transients. Thus, it can be said that the behavior of HBMMC to disturbances is better than the behavior shown by the 2level converter and the NPC converter.

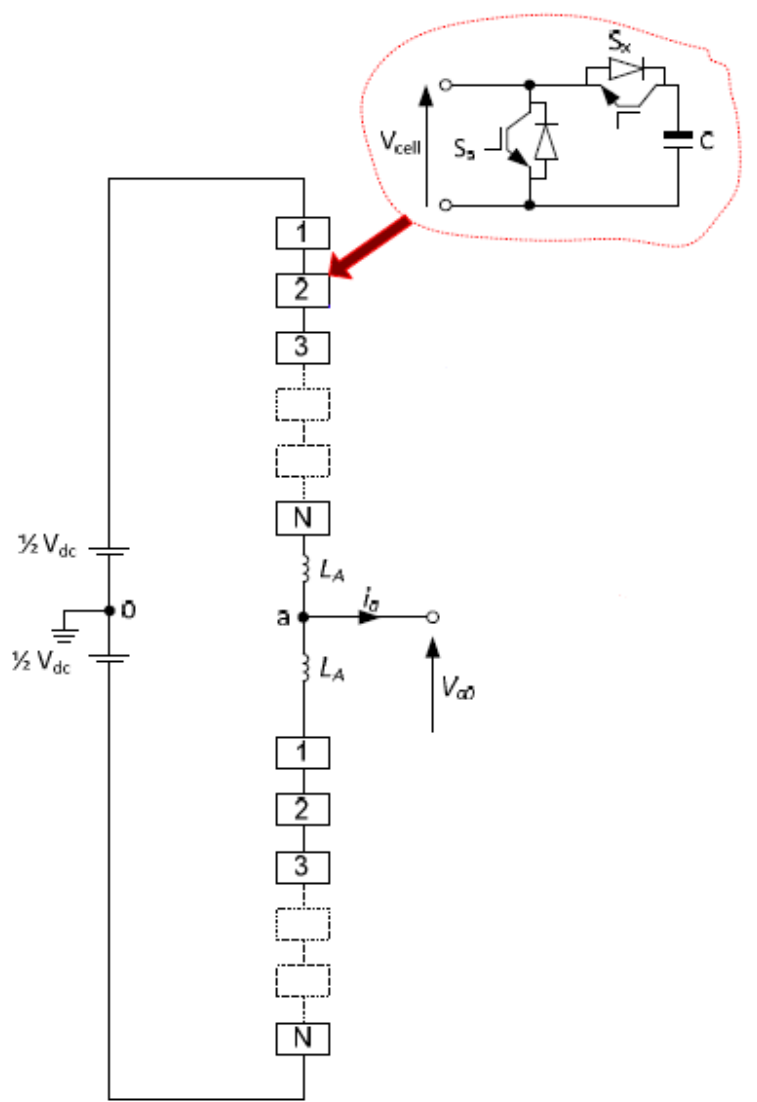

Fig. 3. HBMMC [2].

HBMMC MTDC systems are capable to withstand major transient conditions without increasing the risk of system collapse. Furthermore, the combination of an effective power management scheme with fault current limiters 
(FCL) can reduce the risk of DC faults in MTDC systems $[5]$.

\section{2) Full Bridge Modular Multilevel Converters (FBMMC)}

H-Bridge Modular Multilevel Converters (Fig. 4) offer DC fault reverse blocking that improves fault ride-through capability, as it reduces converter station damage from overcurrents during DC side faults. DC fault reverse blocking capability is the ability to stop the active power exchange between AC and DC sides, as well as the reactive power flow between converter and $\mathrm{AC}$ side.

The magnitude of the transient components of the fault current (discharge currents from converters capacitors and DC cable stray capacitance) is much higher than that of the grid contribution. Also, it has to be taken into account that the capacitor's discharge current's influences the recovery time [3-4].

Thus, in back to back configurations, converter topologies with no DC link capacitors provide better fault ridethrough characteristics and, at the same time, cell capacitors do not contribute to the DC fault current when the gate signals to the converter switches are inhibited. Combining the removal of the DC link capacitor and the DC fault reverse blocking capability, it is possible to recover the HVDC network without interruption from a DC fault (temporary or permanent) in a short time. Therefore, this option reduces the risk for the converters or maintaining the AC network stability [6-7].

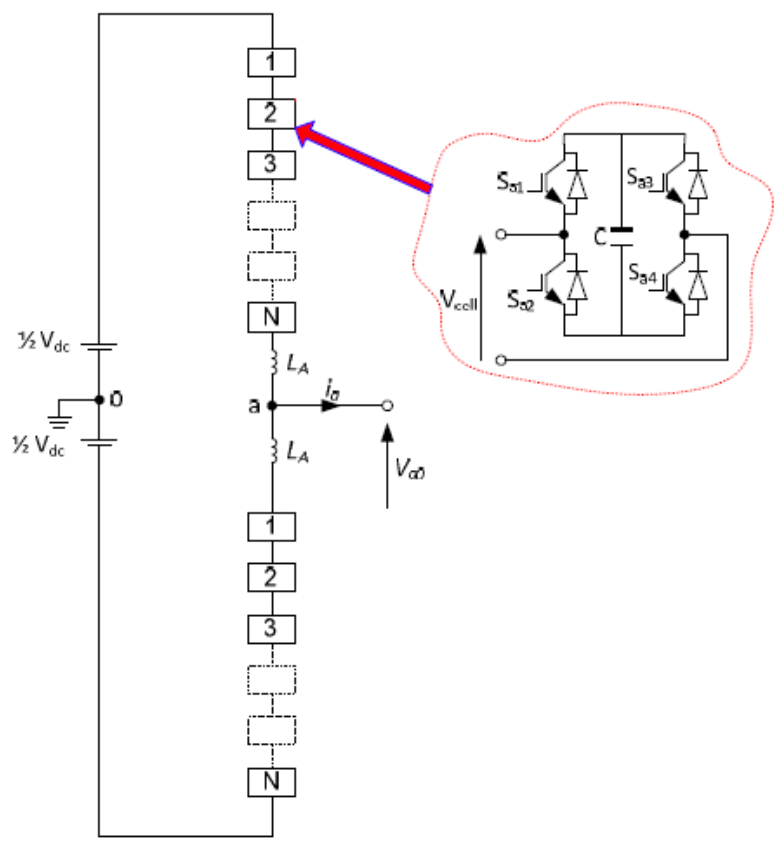

Fig. 4. FBMMC [11].

The main disadvantage of FBMMC topology is that the power transfer capability is zero during the DC fault period, so the AC side dynamic may be affected. However, this system has strong ability to ride through serious DC faults, making it is suitable for MTDC applications.

\section{3) Hybrid VSC-MMC with AC cascaded FB cells}

This kind of converter has inherent DC fault reverse blocking capability. This characteristic improves resilience to DC side faults. By coordinating with the HVDC converter station the following advantages can be obtained [1][8]:

- Eliminate AC grid contribution to the fault and minimize converter failure due to inrush currents.

- Provide controlled recovery without interruption, without opening $\mathrm{CBs}$ from the $\mathrm{AC}$ side.

- Improve voltage stability, reducing reactive power consumption during DC faults.

\section{4) Alternate Arm Converter(AAC)}

Alternate Arm Converter is a hybrid between the FBMMC and the 2-level converter that is used in the form of director switches in each arm (Fig. 5). The director switch is made of series-connected IGBTs, so that the switch can stand the maximum voltage possible when it is in the open state, by combining stacks of FB cells with director switches. This topology is able to generate an almost harmonic-free AC current [5-7].

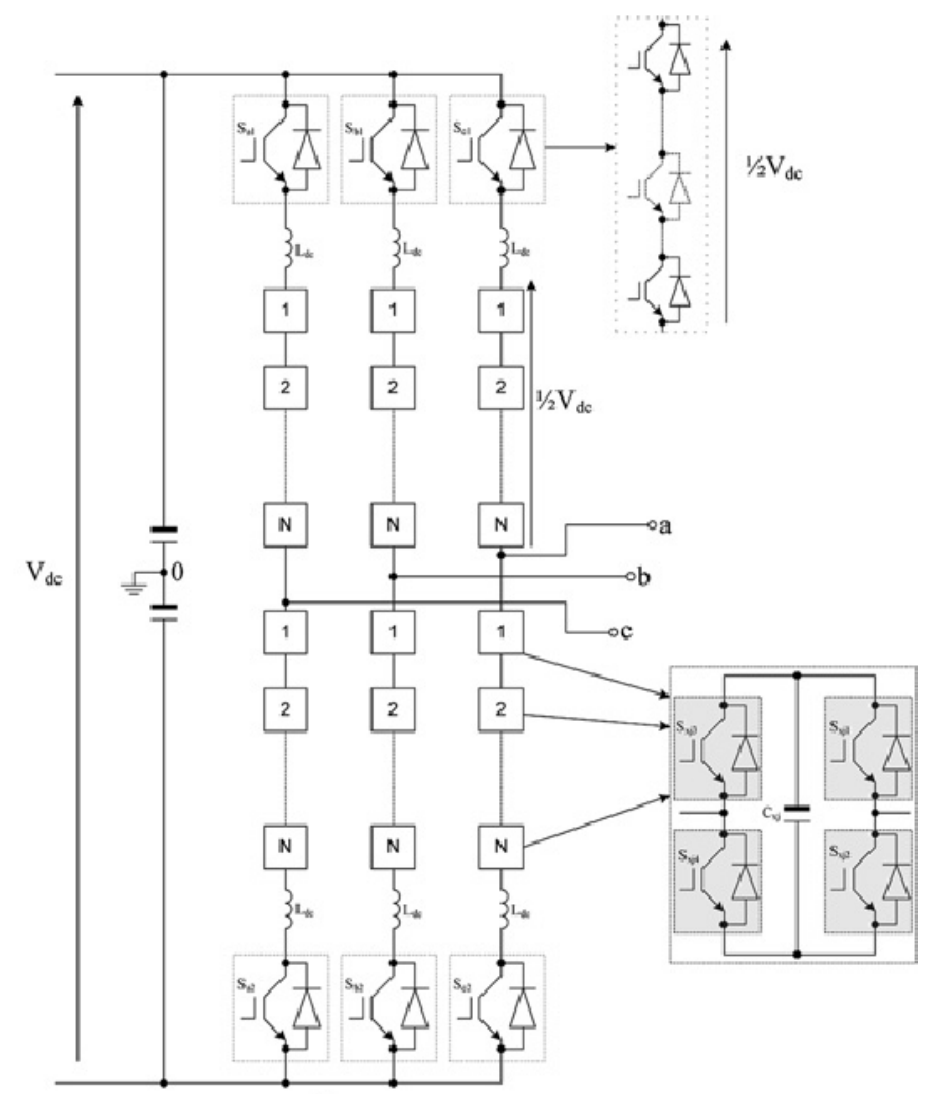

Fig. 5. AAC [5].

This converter can produce negative voltage higher than the normal positive voltage from its stack of cells. Thus, when the DC bus voltage drops, it does not prevent reactive power exchange with the other side. Since the arms of the AAC are still operational, the entire converter can act as a STATCOM. This STATCOM mode of 
managing the converter during the fault can help support the AC grid during a DC outage [9-10].

The high FRT capability of AAC enhances the system reliability, making possible its use in overhead lines to protect from DC faults.

\section{AC Fault Ride Through}

When a fault in the AC side occurs, it is important that the resulting voltage rise on the DC side, as well as the current and voltage stresses on the switching devices remain under control. Generally, VSC-HVDC response to AC-side faults is excellent although it may vary depending on converter topologies [4][11]:

- 2-level converters adjust their reactive power exchange at the PCC to support grid voltage and they are able to recover when the fault is cleared without significant difficulties

- Neutral Point Clamped (NPC) converters (Fig.2) vary the exchange of active and reactive power when the voltage collapses. Recovery is achieved without exposing the converter to major current or voltage stresses, mainly due to the converter current control and the voltage balancing strategy of the capacitors.

- Modular Multilevel Converters (MMC) provide such a high quality waveform to the interfacing transformer that the inclusion of reactors and AC filters is not necessary. Besides, MMC recovers quickly after a fault in the $\mathrm{AC}$ side. When the voltage at the PCC drops or additional load is introduced, it adjusts the active and reactive power. Converter switches are never exposed to voltage or current stresses since the modular converter cell's capacitor is not compromised.

Regarding Multiterminal HVDC (MTDC) systems, its dynamic response needs further research since multiple controllers (current controller, Phase Locked Loop, PQ control, etc.) may affect the transient response of the MTDC system to an AC fault.

To summarize, it can be said that although AC side fault response is good for the different topologies, MMC have the most satisfactory AC FRT capability.

\section{Conclusion}

Whereas VSC-HVDC systems show very good fault behaviour in case of $\mathrm{AC}$ side faults, in case of DC side faults, classic VSC-HVDC has traditionally relied on control strategies for FRT. In this regard, the converter topology used may actively contribute to improve FRT behaviour. Thus, the back to back configuration converter topologies with no DC link capacitors contribute to better fault ride-through abilities, as the cell capacitors do not contribute to the DC fault current when the gate signals to the converter switches are inhibited.

Another interesting feature is that of DC fault reverse blocking capability converters, as these converters show a better transient behaviour and improved DC fault ridethrough capability.

Thus, it is possible to conclude that 2-level, NPC and HBMMC converters do not show a satisfactory behaviour when DC side faults occur. The better topologies in this field are FBMMC and other hybrid topologies, such as AC side cascaded FB cells or Alternate Arm Converters.

Finally, regarding VSC-based MTDC grids, it can be said that MMC-HVDC may contribute to the improvement of FRT in these networks. Nevertheless, much research has yet to be done regarding MTDC response to both AC and DC side faults.

\section{References}

[1] Adam G, Finney S, Williams B, Trainer D, Oates C, Critchley D. Network fault tolerant voltage-sourceconverters for high-voltage applications. . 2010:1-5 A. Author1, Book Title, Publisher, City (1996), pp. 154-162. [2] Grain A, AHMED K, SINGH N, FINNEY S, WILLIAMS B. H-bridge modular multilevel converter (M2C) for high-voltage applications. . 2011

[3] Adam G, Kalcon G, Finney S, Holiday D, Anaya-Lara O, Williams B. HVDC network: DC fault ride-through improvement. . 2011:6-8.

[4] Adam GP, Finney S, Bell K, Williams B. Transient capability assessments of HVDC voltage source converters. . 2012:1-8.

[5] Adam GP, Anaya-Lara O, Burt G. Multi-terminal dc transmission system based on modular multilevel converter. . 2009:1-5.

[6] Merlin M, Green T, Mitcheson P, Trainer D, Critchley D, Crookes R. A new hybrid multi-level voltage-source converter with DC fault blocking capability. . 2010:1-5.

[7] Zhao C, Xu J, Li T. DC faults ride-through capability analysis of full-bridge MMC-MTDC system. Science China Technological Sciences. 2013;56(1):253-261.

[8] Adam GP, Ahmed KH, Finney SJ, Bell K, Williams BW. New breed of network fault-tolerant voltage-sourceconverter HVDC transmission system. Power Systems, IEEE Transactions on. 2013;28(1):335-346.

[9] Merlin MM, Green TC, Mitcheson PD, et al. The alternate arm converter: A new hybrid multilevel converter with DC-fault blocking capability. . 2014.

[10] Hu P, Jiang D, Zhou Y, Guo J, Lin Z, Liang Y. Modulation and control of a new alternate arm multilevel converter for high $\square$ voltage direct current system with direct current fault ride $\square$ through capability. International Transactions on Electrical Energy Systems. 2013.

[11] Adam GP, Finney S, Bell K, Williams B. Transient capability assessments of HVDC voltage source converters. . 2012:1-8 